\title{
Gastroprotective Effect of Green Algae Extract (Ulva lactuca L) on Gastric Rats
}

\author{
Wahyu Widyaningsih*, Siti N. Afdaliah \\ Faculty of Pharmacy, Universitas Ahmad Dahlan, Yogyakarta - Indonesia
}

Submitted 9 July 2019; Revised 19 February 2020; Accepted 30 Maret 2020; Published 10 June 2020

*Corresponding author: widyaningsihwahyu@yahoo.com

\begin{abstract}
Gastric ulcer is a disease of the digestive tract characterized by mucous damage to secretion of gastric acid and pepsin. One of the potential gastroprotector plants is green algae. The purpose of this study was to examine the gastroprotective effect of ethanol extract of green algae (EEGH) Ulva lactuca $\mathrm{L}$ on the gastric of ethanol-induced rats. This study used 36 rats, divided into 6 groups. Group I is a normal group. Group II negative control, ethanol $96 \%$ induced. Group III positive control, given comparison of ranitidine dose of $15.75 \mathrm{mg} / \mathrm{kgBW}$. Groups IV, V and VI were given multilevel EEGH, namely 125, 250 and $500 \mathrm{mg} / \mathrm{kgBW}$. The treatment was carried out for 14 days, on the 14th day ethanol $96 \%$ was induced and then dissected. Research data on gastric ulcer index and protection ratio were analyzed using One Way ANOVA with a confidence level of 95\%. The results of the EEGH statistical test dose of $500 \mathrm{mg} / \mathrm{kgBW}$ with negative controls showed a significant difference with $\mathrm{p}$ value of 0.013 $(\mathrm{p}<0.05)$. The EEGH $500 \mathrm{mg} / \mathrm{kgBW}$ has the ability as an effective gastroprotector, as shown from the gastric ulcer index value of 0.5 and the protection ratio of $78.94 \%$.
\end{abstract}

Keywords: Ethanol, gastroprotector, protection ratio, ulcer index, Ulva lactuca L.

\section{Efek Gastroprotektif Ekstrak Etanol Ganggang Hijau (Ulva lactuca L) pada Lambung Tikus}

\begin{abstract}
Abstrak
Tukak lambung merupakan penyakit pada saluran pencernaan ditandai oleh adanya kerusakan mukosa sekunder akibat sekresi asam lambung dan pepsin. Salah satu tanaman yang berpotensi sebagai gastroprotektor adalah ganggang hijau. Tujuan penelitian ini adalah menguji efek gastroprotektif ekstrak etanol ganggang hijau (EEGH) Ulva lactuca, L. pada lambung tikus yang diinduksi etanol. Penelitian ini menggunakan 36 ekor tikus, dibagi kedalam 6 kelompok. Kelompok I adalah kelompok normal. Kelompok II kontrol negatif, diinduksi etanol 96\%. Kelompok III kontrol positif, diberi pembanding ranitidin dosis $15,75 \mathrm{mg} / \mathrm{kgBB}$. Kelompok IV, V dan VI diberi EEGH dosis bertingkat yaitu 125,250 dan $500 \mathrm{mg} / \mathrm{kgBB}$. Perlakuan dilakukan selama 14 hari, pada hari ke-14 tikus diinduksi etanol 96\% lalu dibedah. Data penelitian indeks tukak lambung dan rasio proteksi dianalisis dengan uji Kolmogorov-Smirnov dan uji Levene, selanjutnya di uji menggunakan One Way ANOVA dengan taraf kepercayaan 95\%. Hasil uji statistik EEGH dosis $500 \mathrm{mg} / \mathrm{kgBB}$ dengan kontrol negatif menunjukkan adanya perbedaan signifikan dengan nilai p 0,013 ( $<<0,05)$, sedangkan EEGH dosis $125 \mathrm{mg} / \mathrm{kgBB}$ dan $250 \mathrm{mg} / \mathrm{kgBB}$ tidak berbeda signifikan dengan kontrol negatif. Ekstrak etanol ganggang hijau Ulva lactuca, L. dosis $500 \mathrm{mg} / \mathrm{kgBB}$ memiliki kemampuan sebagai gastroprotektor yang efektif, dilihat dari nilai indeks tukak lambung yaitu 0,5 dan rasio proteksi yaitu 78,94\%.
\end{abstract}

Kata Kunci: Etanol, indeks tukak, gastroprotektor, rasio proteksi, Ulva lactuca L. 


\section{Pendahuluan}

Tukak lambung merupakan suatu penyakit atau gangguan pada saluran pencernaan yang ditandai oleh adanya kerusakan mukosa sekunder akibat sekresi asam lambung dan pepsin. Berdasarkan penelitian di Amerika, sekitar 31-57\% penderita tukak lambung disebabkan karena infeksi bakteri Helicobacter pylori dan penggunaan non steroidal anti inflammatory drugs (NSAIDs). ${ }^{1,2}$ Ketidakseimbangan faktor agresif dan faktor defensif merupakan awal terjadinya tukak lambung. Salah satu faktor agresif yang dapat meningkatkan resiko erosi mukosa lambung dan pembentukan ulkus adalah etanol. Etanol dapat meningkatkan produksi reactive oxygen species (ROS) dan menurunkan kadar antioksidan seluler sehingga dapat merusak sawar mukosa. ${ }^{3}$

Pengobatan farmakologi

yang digunakan untuk mengatasi tukak lambung antara lain antasida, proton pump inhibitor (PPI), antagonis reseptor $\mathrm{H}-2$, prostaglandin, sukralfat dan bismut subsitrat., ${ }^{4,5}$ Selain obat-obat tersebut, masyarakat masih menggunakan tanaman obat tradisional untuk menyembuhkan penyakit tukak lambung. ${ }^{6}$ Salah satu tanaman yang potensi sebagai gastroprotektor yaitu ganggang hijau ( $U$. lactuca, L). Menurut beberapa penelitian yang telah dilakukan, menunjukkan bahwa ekstrak etanol dari $U$. lactuca memiliki potensi sebagai antihiperlipidemia, antioksidan, antiangiogenesis dan antihepatitis. ${ }^{7}$

Tanaman ganggang hijau (U. lactuca, L) memiliki kandungan fitokimia antara lain alkaloid, karbohidrat, protein dan asam amino, sterol, saponin, fenol, amilum, kuinon, flavonoid, glikosida jantung dan klorofil. ${ }^{7,8}$ Berdasarkan aktivitas antioksidan yang dimiliki, ekstrak etanol U. lactuca, L. diharapkan dapat berperan sebagai gastroprotektor terhadap induksi etanol dengan cara menangkap radikal bebas dan meningkatkan kerja enzim antioksidan, sehingga mencegah terjadinya kerusakan pada sel.

\section{Metode}

2.1. Alat dan Bahan
Alat yang digunakan antara lain peralatan maserasi yaitu toples dan pengaduk, timbangan analitik (Kern: ABS 220-4 Analytical Balance), seperangkat alat rotary evaporator (IKA Rotary Evaporator RV 10 Digital V), pompa vakum, waterbath (Yenaco: Shaking Waterbath YNC-SWB50L), kandang, alat bedah, suntikan oral untuk tikus (Terumo), cawan porselin (Pyrex) dan peralatan gelas yang lazim digunakan (Pyrex).

Bahan-bahan yang digunakan dalam penelitian ini antara lain ekstrak etanol ganggang hijau (EEGH) Ulva lactuca, L., hewan uji tikus galur Wistar dewasa usia 2-3 bulan (BB 180-200 gram), etanol 96\% (Brataco), larutan pembawa poly-vinyl pirolidon (PVP) 1\% (Linkwell), ranitidin (Hexpharm), aquades, pakan (BR2) dan minum hewan.

\subsection{Ekstraksi Ganggang Hijau}

Serbuk kering ganggang hijau dimaserasi menggunakan pelarut etanol 96\% dalam wadah tertutup. Pengadukan mekanik dilakukan pada 3 jam perendaman pertama kemudian dibiarkan selama 48 jam sambil diaduk. Setelah perendaman, pelarut dipisahkan dari ampas simplisia menggunakan kain penyaring khusus. Maserat yang diperoleh kemudian diuapkan dengan menggunakan alat rotary evaporator pada suhu $40^{\circ} \mathrm{C}$ hingga diperoleh ekstrak kental.

Ekstrak etanol ganggang hijau $U$. lactuca, L. dibuat dalam bentuk larutan suspensi untuk selanjutnya digunakan sebagai sampel uji dalam menentukan efek gastroprotektif terhadap parameter indeks tukak lambung dan rasio proteksi. Ekstrak etanol ganggang hijau $U$. lactuca, L. dilarutkan dalam larutan pembawa PVP 1\%.

\subsection{Uji In Vivo Efek Gastroprotektif} Ekstrak Etanol Ganggang Hijau

Penelitian uji efek gastroprotektif ekstrak etanol ganggang hijau U. lactuca, L. dilakukan selama 14 hari perlakuan, menggunakan hewan uji tikus Wistar yang berusia 2-3 bulan. Tikus dibagi menjadi 6 
kelompok perlakuan, tiap kelompokberjumlah 6 ekor tikus. Hewan uji tikus diberi makan dan minum secukupnya. Sebelum perlakuan, tikus diadaptasikan selama 1 minggu dengan kondisi laboratorium. Kelompok hewan uji dibagi menjadi:

1) Kelompok I : kontrol normal, tikus normal yang hanya diberi pakan dan minum standar.

2) Kelompok II : kontrol negatif, tikus diberi pakan dan minum standar.

3) Kelompok III : kontrol positif, selain diberi pakan minum standar, tikus diberi perlakuan obat ranitidin dosis $15,75 \mathrm{mg} /$ $\mathrm{kgBB}$ sebagai pembanding.

4) Kelompok IV : kelompok perlakuan, tikus diberi ekstrak etanol ganggang hijau dosis $125 \mathrm{mg} / \mathrm{kgBB} 1 \mathrm{x}$ sehari.

5) Kelompok V : kelompok perlakuan, tikus diberi ekstrak etanol ganggang hijau dosis $250 \mathrm{mg} / \mathrm{kgBB} 1 \mathrm{x}$ sehari.

6) Kelompok VI : kelompok perlakuan, tikus diberi ekstrak etanol ganggang hijau dosis $500 \mathrm{mg} / \mathrm{kgBB} 1 \mathrm{x}$ sehari.

Satu jam setelah pemberian perlakuan hari ke-14, hewan uji pada kelompok II, III, IV, V, dan VI diinduksi etanol 96\% dengan dosis $2 \mathrm{ml} / 200 \mathrm{gBB}$ secara per oral. Tikus kemudian dipuasakan selama 24 jam lalu dikorbankan dengan diuapi karbon dioksida. Pembedahan dilakukan terhadap hewan uji, lambung diisolasi dan dibuka, selanjutnya dibersihkan dengan larutan $\mathrm{NaCl} 0,9 \%$, dibentangkan di permukaan datar dan diamati lesi tukak yang terbentuk..$^{9,10}$

\subsubsection{Pengamatan Lesi Tukak Lambung}

Tukak lambung dihitung dan di skoring dengan metode skoring Hanafi dkk (2014), yang di modifikasi. Modifikasi dilakukan agar jumlah tukak yang terbentuk $<3$, dapat dikategorikan dan di skoring. Cara skoring metode ashok ditentukan berdasarkan jumlah lesi atau tukak yang terbentuk pada mukosa lambung tikus dengan memberikan skor 0 sampai 3. Tukak dihitung 1 jika terdapat kerusakan atau hilangnya jaringan pada lapisan mukosa lambung di satu titik dan seterusnya. ${ }^{11,12}$

Data indeks tukak lambung dan rasio proteksi dianalisis dengan uji KolmogorovSmirnov dan uji Levene untuk mengetahui normalitas dan homogenitas data. Selanjutnya diuji dengan analisis One-Way ANOVA jika data tersebut terdistribusi normal dan homogen, tingkat signifikansi diuji dengan SPSS student sample t-test dengan taraf kepercayaan $95 \%$. Jika data tidak terdistribusi normal dan tidak homogen maka dilakukan uji statistik non-parametrik dengan uji KruskalWallis untuk melihat ada atau tidaknya perbedaan bermakna antara kelompok hewan uji, dilanjutkan dengan uji Mann-Whitney untuk mengetahui kelompok mana yang memiliki perbedaan bermakna.

\section{Hasil}

3.1. Hasil uji makroskopis lambung Setelah dilakukan perlakuan terhadap lambung tikus dengan induksi etanol pada berbagai kelompok hewan uji, terlihat jelas perbandingan antar kelompok perlakuan. Gambaran makroskopis mukosa lambung pada masing-masing kelompok perlakuan uji efek gastroprotektif ekstrak etanol ganggang hijau U. lactuca, L. dapat dilihat pada Gambar 1.

3.2. Hasil uji efek gastroprotektif terhadap indeks ulser

Setelah dilakukan perhitungan indeks ulser berdasarkan perbandingan antara jumlah total skor dengan jumlah hewan masingmasing kelompok, data indeks ulser kemudian dibandingkan dengan kelompok kontrol.13 Data rata-rata skoring tukak lambung dan nilai indeks ulser ekstrak etanol U. lactuca $\mathrm{L}$ dapat dilihat pada Tabel 1 dan Gambar 2.

\subsection{Hasil Uji Derajat Putih}

Setelah dilakukan perhitungan rasio proteksi yang diperoleh dari rumus ${ }^{14}$ :

$$
\begin{gathered}
\% \text { Rasio Proteksi }=100 \%-\left[\frac{\text { IU kelompok perlakuan }}{\text { IU kelompok kontrol negatif }} \times 100 \%\right] \\
\text { Data grafik nilai rasio proteksi }
\end{gathered}
$$
ekstrak etanol U. lactuca L dapat dilihat pada Gambar 3. 


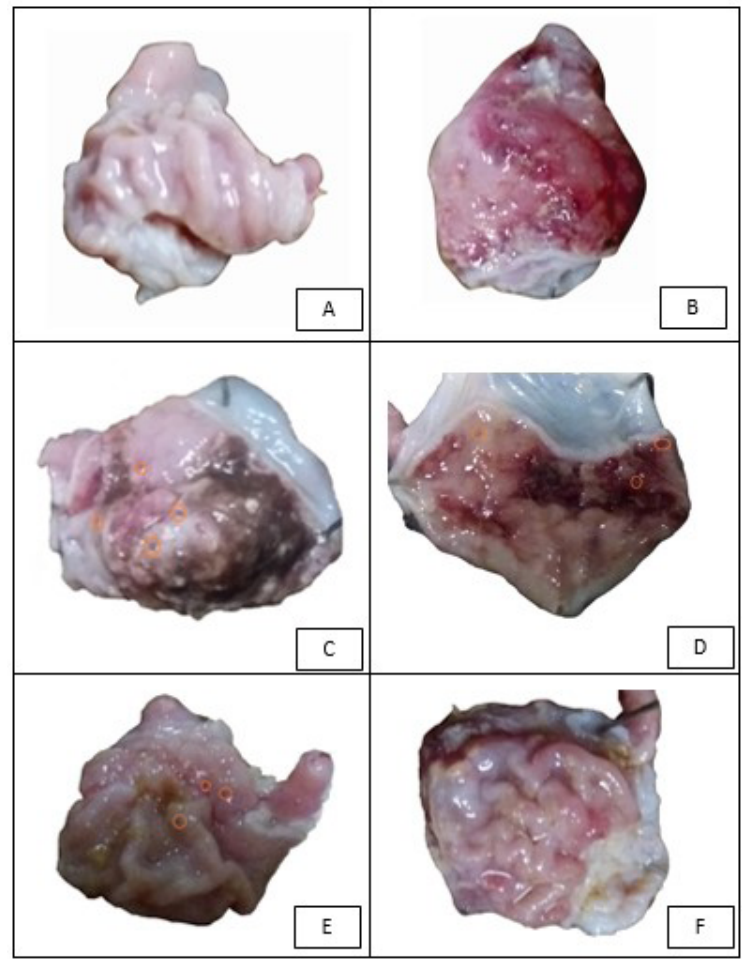

Ket: yang dilingkari adalah tukak lambung yang terbentuk.

A. Kelompok kontrol normal, lambung terlihat berwarna normal dan tidak terdapat perdarahan maupun tukak yang terbentuk.

B. Kelompok kontrol positif, terdapat bintik bintik pendarahan atau hiperemia.

C. Kelompok kontrol negatif, terdapat tukak yang terbentuk dan terjadi pendarahan pada mukosa lambung.

D. Kelompok perlakuan dosis $125 \mathrm{mg} / \mathrm{kgBB}$, ada tukak yang terbentuk dan terjadi hiperemia.

E. Kelompok perlakuan dosis $250 \mathrm{mg} / \mathrm{kgBB}$, terdapat tukak pada mukosa lambung.

F. Kelompok perlakuan dosis $500 \mathrm{mg} / \mathrm{kgBB}$, tidak ada tukak yang terbentuk dan tidak terjadi hiperemia maupun pendarahan.

Gambar 1. Gambaran makroskopis kerusakan lambung yang diinduksi etanol 96\% pada berbagai kelompok perlakuan.

\section{Pembahasan}

4.1. Gambaran Makroskopis Kerusakan Lambung

Berdasarkan pada Gambar 1, kondisi lambung pada kelompok normal terlihat berwarna normal, tidak terdapat hiperemia, pendarahan maupun tukak yang terbentuk. Pada kelompok kontrol positif, terdapat bintik-bintik pendarahan atau hiperemia pada lambung tetapi tidak ada tukak yang terbentuk, sedangkan pada kelompok negatif, terlihat adanya tukak yang terbentuk dan terjadi pendarahan pada mukosa lambung.

Tukak yang terbentuk pada kontrol negatif disebabkan oleh etanol, sesuai dengan teori bahwa etanol dapat menginduksi tukak lambung. Pemberian etanol yang berlebihan dapat merusak sawar mukosa lambung dengan cara meningkatkan produksi radikal bebas berupa reactive oxygen species (ROS), sehingga menurunkan kemampuan antioksidan seluler dalam mempertahankan keseimbangan antara faktor agresif dan defensif, akibatnya kerusakan mukosa tidak dapat dihindari. ${ }^{2}$ Sedangkan pada kontrol positif tidak terbentuk tukak lambung, artinya bahwa kontrol positif yang menggunakan perlakuan suspensi ranitidin memiliki efek perlindungan terhadap lambung.

Pada kelompok kontrol negatif dengan kelompok perlakuan EEGH U. lactuca, L. dosis $125 \mathrm{mg} / \mathrm{kgBB}$ dan $250 \mathrm{mg} / \mathrm{kgBB}$ memiliki nilai $\mathrm{p}>0,05$, sehingga dapat disimpulkan tidak terdapat perbedaan secara signifikan, yang berarti EEGH U. lactuca, L. pada dosis $125 \mathrm{mg} / \mathrm{kgBB}$ dan $250 \mathrm{mg} / \mathrm{kgBB}$ belum dapat melindungi mukosa lambung, sebaliknya antara kelompok kontrol negatif dengan kelompok perlakuan EEGH $U$. lactuca, L. pada dosis $500 \mathrm{mg} / \mathrm{kgBB}$ memiliki perbedaan signifikan dengan nilai signifikansi $0,013<0,05$, yang menunjukkan bahwaEEGH U. lactuca, L. dosis $500 \mathrm{mg} / \mathrm{kgBB}$ memiliki kemampuan dalam melindungi mukosa 
Tabel 1. Rata-rata skoring tukak lambung uji gastroprotektif EEGH U. lactuca, L.

\begin{tabular}{ccc}
\hline Kelompok & Dosis $(\mathrm{mg} / \mathrm{kgBB})$ & Rata-rata Skor $( \pm \mathrm{SD})$ \\
\hline Kontrol Normal & - & $0 \pm 0,00$ \\
Kontrol Positif & 15,75 & $1 \pm 0,40$ \\
Kontrol Negatif & - & $2,375 \pm 0,47$ \\
Ekstrak etanol ganggang hijau & 125 & $2,25 \pm 0,28$ \\
$\quad$ U. Lactuca, L. \\
$\begin{array}{c}\text { Ekstrak etanol ganggang hijau } \\
\text { U. Lactuca, L. }\end{array}$ \\
$\begin{array}{c}\text { Ekstrak etanol ganggang hijau } \\
\text { U. Lactuca,L. }\end{array}$
\end{tabular}

lambung. Demikian juga pada kelompok perlakuan EEGH U. lactuca, L. dosis $500 \mathrm{mg} /$ $\mathrm{kgBB}$ memiliki efek perlindungan yang besar terhadap lambung dibandingkan kelompok kontrol positif ranitidin.

\subsection{Indeks Tukak Lambung}

Berdasarkan data indeks tukak lambung pada Gambar 2, dapat disimpulkan bahwa ekstrak etanol ganggang hijau $U$. lactuca, L. memiliki efek sebagai gastroprotektor pada dosis $500 \mathrm{mg} / \mathrm{kgBB}$. Hasil indeks ulser menunjukkan kelompok perlakuan EEGH U. lactuca, L. dosis $500 \mathrm{mg} / \mathrm{kgBB}$ memiliki kemampuan dalam melindungi mukosa lambung lebih baik dibandingkan dengan kelompok kontrol positif yaitu perlakuan suspensi ranitidin, terlihat pada Gambar 2, indeks tukak lambung kelompok perlakuan EEGH U. lactuca, L. dosis $500 \mathrm{mg} / \mathrm{kgBB}$ lebih kecil dibandingkan dengan kelompok kontrol positif dan sebaliknya. Hal ini dapat disebabkan karena berbagai hal, diantaranya dosis ranitidin yang mungkin kurang tepat sehingga tidak efektif atau ranitidin kurang poten dalam mengatasi tukak lambung yang diinduksi dengan etanol 96\%.

Menurut penelitian, ranitidin kurang efektif terhadap tukak lambung karena penekanan sekresi asam lambungnya tidak pada daerah basal dari lambung, sehingga ranitidin lebih efektif dalam menghambat sekresi asam lambung akibat dari rangsangan obat muskarinik, stimulasi vagus atau gastrin. ${ }^{15}$ Selain itu, senyawa melatonin lebih efektif daripada ranitidin dalam mencegah terjadi luka pada lambung yang diinduksi oleh stress. ${ }^{16,17}$ Hal tersebut sejalan dengan hasil penelitian ini, karena pada ekstrak etanol ganggang hijau $U$. lactuca, L dosis $500 \mathrm{mg} / \mathrm{kgBB}$ lebih efektif dalam melindungi lambung yang diinduksi etanol, dibandingkan

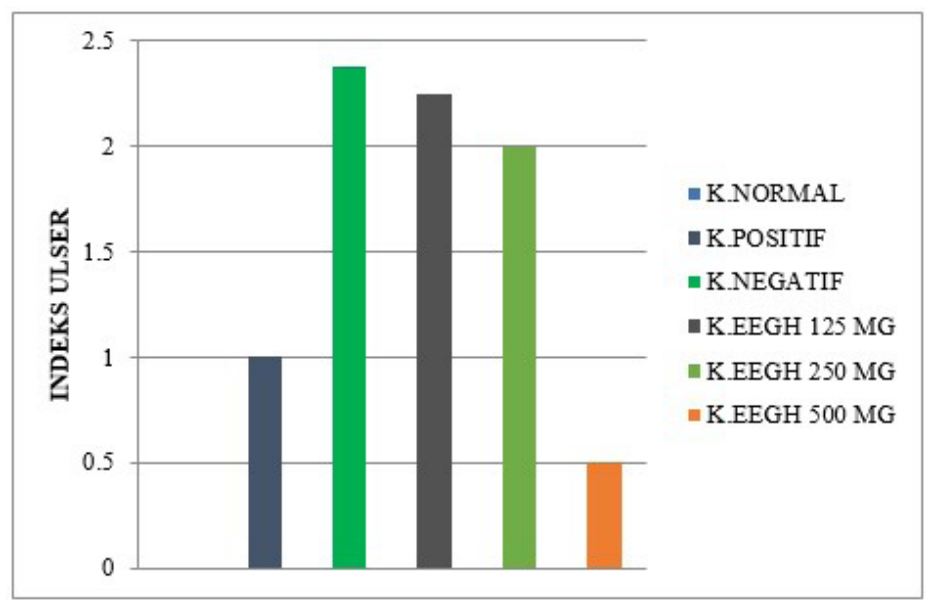

Gambar 2. Grafik nilai indeks ulser lambung tikus yang diinduksi etanol $96 \%$ pada berbagai kelompok perlakuan 


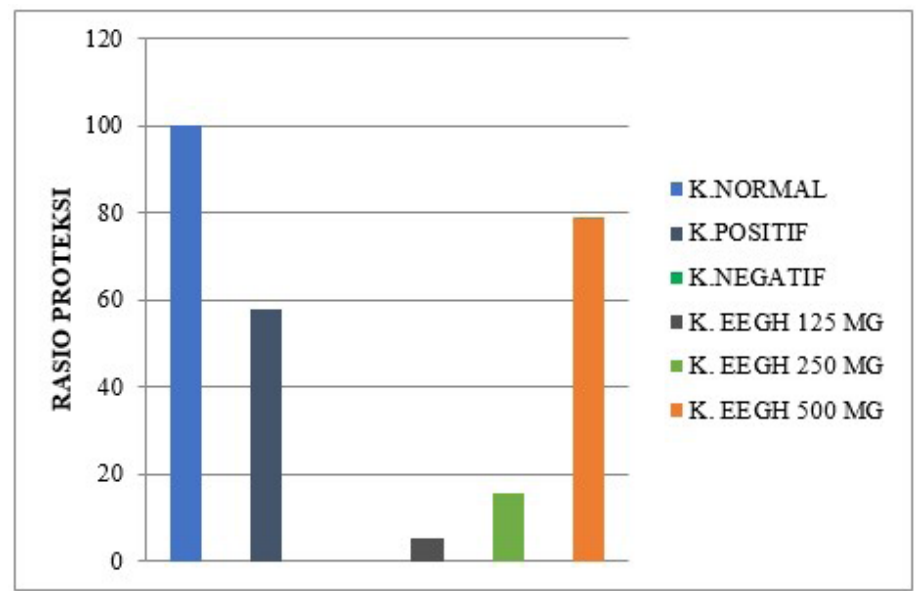

Gambar 3. Grafik nilai rasio proteksi berbagai kelompok perlakuan pada tikus yang diinduksi etanol $96 \%$.

dengan suspensi ranitidin, yang mana telah diketahui bahwa melatonin merupakan zat aktif utama dari tanaman ganggang hijau $U$. lactuca, L.

\subsection{Rasio Proteksi terhadap Tukak Lambung \\ Berdasarkan data rasio proteksi pada} Gambar 3, dapat disimpulkan bahwa ekstrak etanol ganggang hijau $U$. lactuca, L memiliki efek sebagai gastroprotektor pada dosis 500 $\mathrm{mg} / \mathrm{kgBB}$. Hasil rasio proteksi menunjukkan kelompok perlakuan EEGH U. lactuca, L dosis $500 \mathrm{mg} / \mathrm{kgBB}$ memiliki kemampuan dalam melindungi mukosa lambung lebih baik dibandingkan dengan kelompok kontrol positif yaitu perlakuan suspensi ranitidin, persen rasio proteksi EEGH U. lactuca, L. dosis $500 \mathrm{mg} / \mathrm{kgBB}$ lebih besar yaitu 78,94\% dibandingkan dengan kelompok kontrol positif perlakuan ranitidin yaitu sebesar $57,89 \%$.

Efek perlindungan EEGH U. lactuca, L. terhadap tukak lambung yang diinduksi etanol pada dosis $500 \mathrm{mg} / \mathrm{kgBB}$ lebih besar dari pada dosis $125 \mathrm{mg} / \mathrm{kgBB}$ dan $250 \mathrm{mg} / \mathrm{kgBB}$, dapat disebabkan karena dengan peningkatan dosis, maka semakin besar pula kandungan zat aktif pada EEGH U. lactuca, L. yang akan memberikan efek sebagai gastroprotektor, sehingga dengan efektif dapat mencegah terbentuknya luka atau erosi lambung yang disebabkan oleh induksi etanol.

Etanol yang diinduksikan cepat berpenetrasi kedalam mukosa lambung, melepaskan radikal bebas dan meningkatkan permeabilitas mukosa sehingga memungkinkan difusi balik $\mathrm{HCl} .{ }^{18,19}$ Selain itu, dapat menyebabkan erosi lambung, disebabkan karena dalam proses metabolisme etanol menghasilkan produk oksidasi berupa asetaldehid dan asetat yang bersifat toksik bagi sel dan jaringan. ${ }^{20}$

Melatonin sebagai zat aktif utama pada ganggang hijau diduga kuat merupakan senyawa yang berperan penting sebagai gastroprotektor. Melatonin dapat mencegah terjadinya cedera pada sel, jaringan, dan organ maupun sistem organ yang disebabkan oleh stres oksidatif. ${ }^{16}$ Melatonin sebagai antioksidan berperan dalam memangsa radikal bebas secara langsung, menstimulasi enzim antioksidan, meningkatkan fosforilasi oksidatif mitokondria dan menurunkan kebocoran elektron sehingga mengurangi pembentukan radikal bebas. ${ }^{16}$

Selain melatonin, terdapat beberapa senyawa yang terkandung dalam ekstrak etanol ganggang hijau yang juga memiliki aktivitas antioksidan seperti klorofil dan flavonoid yang dapat meningkatkan aktivitas antioksidan dari EEGH U. lactuca, L., sehingga dengan aktivitas antioksidannya baik secara langsung maupun tidak langsung EEGH U. lactuca, L. mampu menangkal radikal bebas atau spesies oksigen reaktif sehingga dapat mencegah terjadinya stres oksidatif yang dapat menyebabkan terganggunya fungsi sel dan jaringan, mencegah terjadinya kerusakan pada sel dan 
jaringan yang dapat mengakibatkan kerusakan pada mukosa lambung. Selain itu, melatonin dan flavonoid mampu meningkatkan aliran darah ke lambung dan meningkatkan produksi mukus sehingga dapat melindungi mukosa lambung. ${ }^{16}$

\section{Simpulan}

Ekstrak etanol ganggang hijau U. lactuca, L. memiliki efek sebagai gastroprotektor dilihat dari parameter indeks tukak lambung dan rasio proteksi. Nilai indeks tukak lambung pada kelompok EEGH dosis $125 \mathrm{mg} / \mathrm{kBB}>250 \mathrm{mg} / \mathrm{kgBB}>500$ $\mathrm{mg} / \mathrm{kgBB}$ yaitu 2,$25 ; 2 ; 0,5$, sedangkan rasio proteksi pada EEGH dosis $125 \mathrm{mg} / \mathrm{kgBB}<$ $250 \mathrm{mg} / \mathrm{kgBB}<500 \mathrm{mg} / \mathrm{kgBB}$ yaitu 5,26 ; 15,$78 ; 78,94 \%$. Ekstrak etanol ganggang hijau $U$. lactuca, L. yang memiliki efek gastroprotektif adalah pada dosis $500 \mathrm{mg} /$ $\mathrm{kgBB}$.

\section{Daftar Pustaka}

1. Yuniati, Achmad H, Sumarno. Pengaruh Outer Membrane Protein Helicobacter pylori terhadap Perubahan Histopatologi Mukosa Lambung dan S-IgA pada Mus musculus Outbred Balb/C. J Exp Life Sci. 2010; 1(1): 20-27.

2. Pratama H. Eradikasi Helicobacter pylori. CDK-243. 2016;43(8):592-95.

3. Irramah M, Julizar, Irawati L. Pengaruh Uncaria gambir roxb terhadap Ulkus Gaster dan Kadar Malondialdehid Hewan Coba yang diinduksi Etanol. Majalah Kedokteran Andalas. 2017;40(1): 1-10. http://dx.doi.org/10.22338/mka.v40. i1.p1-10.2017

4. Lockrey G, Lim L. Peptic Ulcer Disease in Older People. Geriatric Therapeutics. 2011;41(1): 58-61.

5. Widayat W, Ghassani IK, Rijai L. Profil Pengobatan dan DRP's pada Pasien Gangguan Lambung (Dyspepsia, Gastritis, Peptic Ulcer) di RSUD Samarinda. Jurnal Sains dan Kesehatan. 2018; 1(10): 539-547

6. Hanafi NA, Sutjiatmo AB, Vikasari SN. Uji Efek Antitukak Lambung Ekstrak Air Herba Bayam Merah (Amaranthus tricolor L.) terhadap Tikus Wistar Betina. Kartika Jurnal Ilmiah Farmasi. 2014;2(1): 45-50. ISSN 2354-6565

7. Widyaningsih W, Pramono S, Widyarini S, Sugiyanto. Skrining Fitokimia Ekstrak Etanol Ulva lactuca L dengan Metode Kromatografi Lapis Tipis. Media Farmasi. 2016;13(2): 199-211.

8. Abirami RG, dan Kowsalya S. Nutrient and Nutraceutical Potential of Seaweed Biomass Ulva lactuca and Kappaphycus alvarezii. Journal of Agricultural Science and Technology. 2011;5(1): 109-15. ISSN 1939-1250

9. Sigit JI, Ribkah, SoemardjiAA. Efektivitas Preventif Omeprazol Terhadap Efek Samping Tukak Lambung Antiinflamasi Non Steroid (Asetosal) pada Tikus Galur Wistar Betina. Acta Pharmaceutica Indonesia. 2012;37(2): 48-53.

10. Widyaningsih W, Sary EN, Halimah DN, Jannah WOM. Efek Gastroprotektif Kombinasi Perasan Daun Cincau dan Kulit Manggis pada Tikus yang diinduksi Etanol. Trad Med J. 2018;23(2): 103-112

11. Hanafi NA, Sutjiatmo AB, Vikasari SN Uji Efek Antitukak Lambung Ekstrak Air Herba Bayam Merah (Amaranthus tricolor L) terhadap Tikus Wistar Betina. Kartika Jurnal Ilmiah Farmasi. 2014;2(1): 45-50

12. Widyaningsih W, Sary EN, Halimah DN, Jannah WOM. Efek Gastroprotektif Kombinasi Perasan Daun Cincau dan Kulit Manggis pada Tikus yang diinduksi Etanol. Trad Med J. 2018;23(2): 103-12.

13. Pertiwi R. Efek Gastroprotektor Ekstrak Etanol Umbi Garut (Maranta arundinacea L.) terhadap Indeks Tukak Lambung, Rasio Proteksi, Ekspresi protein COX-2 dan Gambaran Histopatologis Lambung pada Tikus Model Tukak Lambung [Tesis]. Yogyakarta: Fakultas Farmasi Universitas Ahmad Dahlan; 2016.

14. Saptarini NM, Suryasaputra D, Saepulhak AM. Analisis Rasio Proteksi Antiulser Sari Buah Pepino (Solanum muricatom Aiton) menggunakan Mencit sebagai Model Hewan Coba. Majalah Obat Tradisional. 2011;16(2): 75-80. 
15. Purnama TNP. Pengaruh Pemberian Ranitidin terhadap Gambaran Histopatologi Putamen Tikus Wistar pada Pemberian Metanol Dosis Bertingkat [Karya Tulis Ilmiah]. Semarang: Fakultas Kedokteran Universitas Diponegoro; 2016.

16. Magierowski M, Jasnos K, Brzozowska I, Drozdowicz D, Sliwowski Z, Nawrot E, Szczyrk U, Kwiecien S. Melatonin as a Therapeutic Factor in Gastric Ulcer Healing Under Experimental Diabetes. Przeg1 Lek. 2013;70(11): 942-6.

17. Salehi B, Sharopov F, Fokou PVT, Kobylinska A, de Jonge L, Tadio K, Sharifi-Rad J, Posmyk MM, Martorell M, Martins N, Iriti M. Melatonin in Medicinal and Food Plants : Occurrence,
Bioavailability and Health Potential for Humans. Cells. 2019;8(681):1-23

18. Hajrezaie M, Golbabapour S, Hassandarvish P, Gwaram NS, Hadi AH, Ali HM. Acute Toxicity and Gastroprotection Studies of a New Schiff Base Derived Copper (II) Complex against Ethanol-Induced Acute Gastric Lesions in Rats. Plos One. 2012;7(12): $1-11$.

19. Pratama MR, Muhartono. Dampak Mengkonsumsi Alkohol terhadap Kesehatan Lambung. Majority. 2019; 8(2): 254-258

20. Usman S. Tingkat Kerusakan Mukosa Lambung pada Tikus Model yang diinduksi Etanol. Mutiara Medika. 2016; 16(1): $33-40$ 